удК 343.985

\author{
A. Ф. Волобуев
}

\title{
МЕТОДИ, ЩО ВИКОРИСТОВУЮТЬСЯ У ДОСУДОВОМУ РОЗСЛІДУВАННІ ЗЛОЧИНІВ
}

Постановка проблеми. Досудове розслідування є першою стадією кримінального провадження, на якій органом досудового розслідування, прокурором здійснюється збирання, перевірка та оцінка доказів для вирішення питання про наявність або відсутність події кримінального правопорушення, вини певної особи в його вчиненні, характеру і розміру заподіяної шкоди. Тобто діяльність уповноважених суб'єктів має характер пізнавальної і засвідчувальної діяльності, об'єктом якої є обставини такого специфічного об'єкта, як злочин. I здійснюється вона шляхом проведення слідчо-розшукових дій (зокрема, негласних), як правило, в умовах наявної або очікуваної протидії з боку зацікавлених осіб. Розробленням рекомендацій щодо їх підготовки і проведення займаються такі прикладні наукові галузі, як криміналістика і теорія оперативно-розшукової діяльності (ОРД). У зв'язку з цим у названих юридичних науках використовуються поняття «технічний засіб», «прийом», «операція», «комбінація». Поряд із названими поняттями використовуються також і терміни «методи криміналістики», «методи ОРД», але щодо них у названих науках немає єдності у тлумаченні їнього змісту та співвідношення з іншими поняттями. Як відомо, зрілість будь-якої галузі науки визначається ступенем розробленості іiі понятійного апарату. Із цих позицій у названих науках $€$ певні проблеми, що торкаються методів, які використовуються у досудовому розслідуванні.

Виклад основного матеріалу дослідження. Метод (з грец. methodos - шлях дослідження) - це спосіб пізнання явищ природи і суспільного життя, який розглядається як окремий прийом або система прийомів, що застосовується у якій-небудь галузі діяльності [1, с. 177]. У філософії розрізняють методи емпіричного і теоретичного рівня. Основою емпіричних методів є чуттєве пізнання (відчуття, сприйняття, уявлення). До цих методів належить спостереження, вимірювання, експеримент, порівняння. Власне теоретичні методи спираються на раціональне пізнання (поняття, судження, умовивід) і логічні процедури виводу. До цих методів належить аналіз, синтез, аналогія, абстрагування тощо [2, с. 598-625]. 
Потрібно відзначити, що в криміналістиці і теорії ОРД тісно поєднуються, з одного боку, методи наукового пізнання свого предмета, а з іншого методи практичної діяльності під час здійснення досудового розслідування. Але розрізнення цих аспектів є досить важливим, оскільки в названих видах пізнавальної діяльності вирішуються різні завдання різними суб'єктами, на що нерідко не звертається уваги у відповідних підручниках i навчальних посібниках. Отже, є: 1) методи наукового (теоретичного) пізнання; 2) методи практичного пізнання під час досудового розслідування злочинів.

Методи наукового (теоретичного) пізнання - це ті методи, які використовуються для вивчення предмета науки і накопичення знань про нього. До цих методів можуть бути віднесені такі. Вивчення документів (матеріалів кримінальних проваджень) - це метод, який використовується для накопичення знань про механізм скоєння злочинів і діяльність щодо їх розслідування. Матеріали кримінального провадження (кримінальна справа) є зібранням процесуальних документів, які докладно відображають, з одного боку, обставини скоєння злочину (предмет доказування), а 3 іншого - слідчі ситуації та порядок дій органу дізнання і слідчого. Аналізу піддаються як протоколи слідчих (розшукових) дій (огляду місця події, допитів потерпілих, свідків, підозрюваних, слідчих експериментів), висновки експертиз, так і процесуальні рішення слідчого. У результаті вивчення великої кількості кримінальних справ встановлюються певні закономірності (залежності, зв'язки) між окремими елементами механізму злочинів, які мають статистичний характер (виражаються у відсотковому відношенні частоти їх прояву). Таким же чином встановлюються певні закономірності у діях органів дізнання і слідства - формуванні слідчих ситуацій і використанні певних способів дій та окремих прийомів збирання доказів.

Опитування осіб, які були учасниками слідчих (розшукових) дій, це додатковий метод одержання інформації про предмет дослідження. Його використання зумовлено тим, що у матеріалах кримінальної справи далеко не завжди відображаються усі обставини злочину, які цікавлять дослідника-криміналіста. Як правило, не знаходять відображення у матеріалах справи і тактичні рішення слідчого. Тому в процесі наукового дослідження використовується формалізоване (анкетування) чи неформалізоване (інтерв'ювання) опитування учасників кримінального процесу: працівників правоохоронних органів (оперуповноважених, слідчих, експертів), потерпілих, свідків, засуджених.

Вивчення опублікованої слідчої практики - це метод, який полягає в аналізі надрукованих матеріалів щодо практичного досвіду розслідування окремих злочинів. Такі матеріали містяться у збірниках (бюлетенях), які видаються у системі Міністерства внутрішніх справ і Генеральної прокуратури України для обміну передовим досвідом розслідування злочинів.

Вивчення статистичних даних та аналітичних матеріалів щодо стану злочинності, виявлення і розкриття злочинів за певний період. Такі матеріали періодично готуються у системі Міністерства внутрішніх справ, 
Генеральної прокуратури і Верховного Суду України, є додатковим джерелом інформації про предмет.

Методи практичного пізнання у досудовому розслідуванні злочинів - це ті методи, які використовуються органом досудового розслідування, прокурором для виявлення, фіксації, вилучення, дослідження і використання доказів. Названі методи називають спеціальними методами криміналістики, оскільки вони були сформовані безпосередньо у науці криміналістики (власні криміналістичні методи), або запозичені з інших наук і пристосовані для вирішення завдань розслідування злочинів.

Спеціальні методи криміналістики можна розділити на: 1) методи пізнання, які застосовуються безпосередньо слідчим (прокурором); 2) методи пізнання, які застосовуються шляхом залучення спеціаліста або призначення експертизи (використання спеціальних знань).

Методами пізнання, які застосовуються безпосередньо слідиим (прокурором), є методи, які входять у систему професійної криміналістичної підготовки слідчого. Ці методи вивчаються у навчальному курсі криміналістики під час підготовки фахівців для відповідних підрозділів правоохоронних органів. До таких методів можуть бути зараховані:

- криміналістична діагностика;

- криміналістична ідентифікація;

- встановлення групової належності об'єкта;

- криміналістичні версіі;

- криміналістичне прогнозування;

- методи застосування криміналістичної техніки (фотографування, звуко- і відеозапису);

- методи, які використовуються під час збирання слідів - відображень (трасологія);

- методи криміналістичного дослідження документів;

- методи криміналістичного дослідження зброї і боєприпасів;

- методи використання ознак зовнішності людини та ін.

Названа група методів є частиною змісту криміналістики, їі науковою «продукцією» і становить елемент іiї навчального курсу, орієнтованого на підготовку фахівців для правоохоронних органів.

Методами пізнання, які застосовуються шляхом залучення спеціаліста або призначення експертизи, є методи, запозичені в інших наук. Вони використовуються, як правило, без модифікації шляхом залучення спеціаліста до проведення слідчих (розшукових) дій або проведенням експертизи (ст. 242 КПК України). До таких методів, які найчастіше використовуються у названому аспекті, можуть бути віднесені:

- біологічні методи, які використовуються для дослідження об’єктів біологічного походження (крові та інших виділень організму людини або тварин, частинок шкіри, волосся, частинок рослин тощо);

- антропологічні методи, використання яких $є$ потрібними під час встановлення невідомого злочинця (опис зовнішності), особистості загиблої людини за кістками тощо; 
- фізичні і хімічні методи, які використовуються в аналізі фізичних і хімічних властивостей матеріалів і речовин (речових доказів);

- психологічні методи, що використовуються під час розроблення тактичних прийомів допиту та інших слідчих дій.

Названа група методів належить до сфери використання спеціальних знань під час розслідування злочинів, яка у навчальному курсі криміналістики висвітлюється в окремих темах та спеціальному курсі залежно від профілю підготовки фахівців.

У теорії ОРД серед науковців нині відсутній єдиний підхід до визначення змісту поняття «методи ОРД», його зв'язку з іншими ключовими категоріями цієї галузі знань. Окрім того, з оновленням кримінального процесуального законодавства України, зокрема, з появою інституту негласних слідчих (розшукових) дій виникла потреба в узгодженні фахової термінології оперативно-розшукової діяльності з термінами суміжних наук кримінально-правового циклу. У КПК України 2012 р. окремим оперативно-розшуковим заходам було надано статус слідчих (розшукових) дій через певну процедуру прийняття рішення про їх проведення і з використанням терміна «негласні». Із збереженням своєї сутності негласних оперативно-розшукових способів отримання інформації про ті чи інші обставини вчинення злочинів негласні слідчі дії покликані стати ефективним засобом у збиранні доказів. На нашу думку, в умовах рівноправності сторін обвинувачення і захисту у збиранні доказів під час здійснення кримінального провадження правоохоронні органи повинні мати спеціальний інструмент у формуванні доказової бази щодо тяжких та особливо тяжких злочинів. Особливо у тих випадках, коли ці злочини вчиняються організованими групами.

Водночас поняття методів оперативно-розшукової діяльності є одним із малодосліджених, зокрема, в контексті співвідношення із поняттям оперативно-розшукових заходів. У спеціальній літературі поняття оперативно-розшукових заходів розглядається як ключове у теорії ОРД. Це зумовлено тим, що воно фактично є елементом самого терміна оперативно-розшукової діяльності, зміст якого визначається як система гласних i негласних пошукових, розвідувальних та контррозвідувальних заходів, що здійснюються із застосуванням оперативних і оперативно-технічних засобів (ст. 2 Закону України «Про оперативно-розшукову діяльність»). Тобто оперативно-розшукові заходи є певними елементами зазначеної діяльності, діями уповноважених органів, спрямованими на пошук і фіксацію інформації про злочинну діяльність окремих осіб та груп із метою іiі припинення та в інтересах кримінального судочинства. Але у згаданому Законі не надається визначення поняття оперативно-розшукових заходів, що є суттєвим недоліком, який, на думку фахівців у галузі оперативно-розшукової діяльності, призводить не тільки до непорозумінь у наукових дослідженнях, а й до грубих помилок у практичній діяльності оперативних підрозділів.

Одне $з$ найбільш розгорнутих визначень поняття оперативно-розшукового заходу надав M.А. Погорецький: це сукупність узгоджених, взаємо- 
пов'язаних і поєднаних між собою загальною метою та завданнями дій уповноважених Законом України «Про оперативно-розшукову діяльність» суб'єктів, що здійснюються переважно негласно шляхом використання оперативних сил, засобів, методів та форм [3, с. 65-66]. У наведеному визначенні поняття оперативно-розшукового заходу міститься вказівка на використання певних пізнавальних методів. Отже, під оперативно-розшуковими заходами розуміють такі дії уповноваженого суб'єкта, які спрямовані на отримання відомостей, необхідних для вирішення певних оперативно-тактичних завдань. У цих діях реалізуються різноманітні методи ОРД, одним із яких, наприклад, визнається агентурний метод [4]. У чинному КПК України застосуванню цього методу надано статус окремої негласної слідчої (розшукової) дії (ст. 275 «Використання конфіденційного співробітництва»). Його сутність полягає у встановленні довірливих відносин між представником уповноваженого оперативного підрозділу з фізичною особою на засадах добровільності, неухильного дотримання вимог конспірації в інтересах вирішення завдань оперативно-розшукової діяльності.

У спеціальній літературі іноді оперативно-розшукові заходи фактично ототожнюються з методами ОРД. Так, методами ОРД із посиланням на загальноприйняту термінологію називається опитування (розвідувальне опитування), наведення довідок, збирання зразків для порівняльного дослідження, дослідження предметів і документів, ототожнення особистості, контрольована поставка, оперативний експеримент тощо [5, с. 39].

Використання методів ОРД пов'язано з тим що сучасна злочинність характеризується прихованістю і організованістю, що вимагає відповідної корекції пізнавальних методів. Видається, що така корекція пов'язана з галузевими принципами ОРД конфіденційності і конспіративності. Принцип конфіденційності в оперативно-розшуковій діяльності полягає у таємничих, довірчих відносинах оперативного працівника та особи, яка добровільно погодилась на негласне співробітництво. Із цим принципом тісно пов'язується і конспіративність в ОРД, яка полягає у втаємниченні способів отримання інформації про обставини скоєння злочину. Отже, стосовно осіб, які співпрацюють з оперативно-розшуковими апаратами, вживається термін «конфіденційність», а щодо форм і методів роботи - «конспіративність» [6, с. 141-143]. На нашу думку, на цій підставі обгрунтованим буде розглядати як методи ОРД оперативне спостереження (фізичне і технічне), оперативне порівняння, оперативний експеримент, оперативне опитування. Названі методи покладаються в основу негласних слідчих (розшукових) дій, спрямованих на отримання інформації про злочини та осіб, які їх вчинили або планують вчинити.

Висновки. 3 урахуванням викладеного методи ОРД, що використовуються у досудовому розслідуванні, можна визначити як окремі прийоми або системи прийомів (оперативно-розшукових засобів і заходів) одержання інформації, що застосовуються із дотриманням конфіденційності і конспіративності під час проведення негласних слідчих (розшукових) дій для вирішення завдань кримінального провадження. 


\section{Література}

1. Новий тлумачний словник української мови. Т. 2. - К. : Аконіт, 2006. - 926 с.

2. Философия : [учеб. для вузов] / под общ. ред. В.В. Миронова. - М. : Норма, 2005. - 928 с.

3. Погорецький М.А. Оперативно-розшукові заходи: поняття і види / М.А. Погорецький / / Держава і безпека України. - К., 2005. - № 1 (3). - С. 62-67.

4. Тарасенко В.Є. Агентурний метод у діяльності оперативних підрозділів ОВС України в умовах євроінтеграції / В.Є. Тарасенко / / Роль та місце ОВС у розбудові демократичної правової держави : матер. II Міжнар. наук.-практ. конф. (м. Одеса, 23 квіт. 2010 р.) / Одеський держ. ун-т внутр. справ. - Одеса, 2010. - С. 258-259.

5. Основы оперативно-розыскной деятельности органов внутренних дел : [учеб.] / под ред. Ю.А. Агафонова, Ю.Ф. Кваши. - Краснодар : Краснодар. ун-т МВД России, 2007. - 305 с.

6. Бандурка O.M. Теорія і практика оперативно-розшукової діяльності : [монографія] / О.М. Бандурка. - Харків : Золота миля, 2012. - 620 с.

\section{А н о т а ці я}

Волобуев $A$. Ф. Методи, що використовуються у досудовому розслідуванні злочинів. - Стаття.

Статтю присвячено малодослідженій проблемі методів, що використовуються у досудовому розслідуванні злочинів уповноваженими суб'єктами. 3 урахуванням новел КПК України 2012 р. висвітлюється зміст методів криміналістики та оперативно-розшукової діяльності.

Ключові слова: досудове розслідування, метод, криміналістика, оперативно-розшукова діяльність, слідча (розшукова) дія, конфіденційність, конспіративність.

\section{А н н о т а ци я}

Волобуев $A . \Phi$. Методы, используемые в досудебном расследовании преступлений. Статья.

Статья посвящена малоизученной проблеме методов, используемых в досудебном расследовании преступлений уполномоченными субъектами. С учетом новелл УПК Украины 2012 г. освещается содержание методов криминалистики и оперативно-розыскной деятельности.

Ключевые слова: досудебное расследование, метод, криминалистика, оперативно-розыскная деятельность, следственное (розыскное) действие, конфиденциальность, конспиративность.

\section{S u m m a r y}

Volobuyev A. F. The methods used in the pre-trial investigation of crimes. - Article.

The article is devoted to the little-studied problem of methods used in pre-trial investigation of crimes by authorized subjects. Taking into account the novels of the Criminal Procedural Code of Ukraine in 2012, the content of methods of criminalistics and operational-search activity is covered.

Key words: pre-trial investigation, method, criminalistics, operational-search activity, investigative action, confidentiality, conspiracy. 